\title{
Management of prosthetic graft infection after surgery of the thoracic aorta: Removal of the prosthetic graft is not necessary
}

Enoch Akowuah, MD, MRCS, Pradeep Narayan, FRCS, Gianni Angelini, MD, MCh, FRCS, and Alan J. Bryan, DM, FRCS (C/Th), Bristol, United Kingdom

See related editorial on page 839 .

$\mathrm{P}$ rosthetic graft infection (PGI) after surgery to reconstruct the thoracic aorta is a devastating complication. The reported incidence is between $1 \%$ and $3 \% .^{1}$ Treatment of this complication remains a challenge for surgeons, and chances of a successful outcome are considered low. Mortality rates range from $25 \%$ to $75 \%$, and morbidity in surviving patients is high. ${ }^{2}$

Most reports advocate a management strategy that combines removal of all the prosthetic material, removal of surrounding tissue, and extra-anatomic arterial reconstruction. ${ }^{3-5}$ However, such a major surgical undertaking may not be possible in most cases because of the technically challenging nature of the surgery, and because most patients usually have multiorgan dysfunction caused by sepsis, making the procedure risky.

In this report, we define the outcome and management strategies for PGI after surgery to reconstruct the thoracic aorta. We report our experience of managing PGI with a more conservative approach.

From the Department of Cardiothoracic Surgery, Bristol Heart Institute at The Bristol Royal Infirmary, Bristol, United Kingdom.

Received for publication Feb 9, 2007; accepted for publication Feb 23, 2007.

Address for reprints: Alan J. Bryan DM, FRCS (C/Th), Consultant Cardiac Surgeon, Bristol Heart Institute, Bristol Royal Infirmary, Upper Maudlin Street, Bristol BS2 8HN (E-mail: Alan.Bryan@ubht.swest.nhs.uk).

J Thorac Cardiovasc Surg 2007;134:1051-2

$0022-5223 / \$ 32.00$

Copyright $\odot 2007$ by The American Association for Thoracic Surgery

doi:10.1016/j.jtcvs.2007.02.055

\section{Clinical Summary}

From 1996 to 2005, all the names of patients undergoing prosthetic graft replacement of the thoracic aorta in a single unit were prospectively placed in a database. A retrospective review of case notes was performed.

A diagnosis of PGI was made in patients with signs of sepsis, namely, pyrexia, leukocytosis, and increased C-reactive protein coupled with evidence on computed tomography scanning of perigraft collection or air.

\section{Results}

During the study period, more than 400 consecutive patients underwent graft replacement of the thoracic aorta. The following procedures were undertaken: aortic arch replacement (38 cases, 9.5\%), composite aortic root replacement (162 cases, 40.5\%), and interposition graft to the ascending aorta plus aortic valve replacement (200 cases, $50 \%$ ). The mortality for the entire group was $13 \%$.

Eight patients $(2 \%)$ had PGI. They underwent the following procedures: aortic arch replacement (2 cases), composite aortic root replacement (3 cases), and interposition graft to the ascending aorta plus aortic valve replacement (3 cases). Demographic details for individual patients are shown in Table 1 . The mean age was 63 years (15); 6 were elective cases and 2 were urgent cases.

In 6 patients, PGI was associated with sternal wound sepsis. Of these 6 patients, 5 with sternal wound involvement underwent surgical reexploration, extensive debridement of necrotic tissue within the mediastinum, mediastinal irrigation with dilute Povidine iodine, and sternal reconstruction. All survived. One patient with sternal wound sepsis was treated conservatively. This patient underwent an aortic valve replacement and replacement of the ascending aorta for an intraoperative ascending aortic dissection. A methicillin-resistant Staphylococcus aureus PGI developed in the patient, which was complicated by a pseudoaneurysm of the proximal aortic anastomotic suture line. She died 27 days after the initial surgery.

TABLE 1. Demographic features of the cohort

\begin{tabular}{ccccllll}
\hline Patient & Age & Sex & Euroscore & \multicolumn{1}{c}{ Procedure } & Priority & Redo & Circulatory arrest \\
\hline 1 & 80 & M & 10 & AVR + CABG + composite root replacement & Elective & No & Yes \\
2 & 61 & M & 9 & Aortic homograft root replacement & Emergency & Yes & No \\
3 & 71 & M & 10 & AVR + CABG + composite root replacement & Elective & No & No \\
4 & 34 & M & 8 & AVR + composite root replacement & Elective & No & No \\
5 & 70 & F & 10 & Aortic arch replacement & Elective & No & Yes \\
6 & 49 & M & 13 & AVR + interposition graft & Elective & Yes & No \\
7 & 73 & F & 10 & AVR + interposition graft & Elective & Yes & No \\
8 & 66 & M & 8 & Hemiarch replacement & Emergency & No & Yes
\end{tabular}

$A V R$, Aortic valve replacement; $C A B G$, coronary artery bypass graft. 
TABLE 2. Outcome of the cohort

\begin{tabular}{cclcrrrr}
\hline Patient No. & $\begin{array}{c}\text { Days from surgery } \\
\text { to infection }\end{array}$ & \multicolumn{1}{c}{ Pathogen } & $\begin{array}{c}\text { Sternal wound } \\
\text { involvement }\end{array}$ & Operative procedure & $\begin{array}{c}\text { ICU } \\
\text { stay }\end{array}$ & $\begin{array}{c}\text { Hospital } \\
\text { stay }\end{array}$ & $\begin{array}{c}\text { Outcome } \\
\text { Ond }\end{array}$ \\
\hline 1 & 10 & Staphylococcus aureus & Yes & Mediastinal debridement & 4 & 38 & Survived \\
2 & 6 & Enterobacter D species & Yes & Mediastinal debridement & 26 & 53 & Survived \\
3 & 8 & Coagulase-negative S. aureus & Yes & Mediastinal debridement & 5 & 23 & Survived \\
4 & 30 & Candida albicans & No & Redo aortic root replacement & 2 & 11 & Survived \\
5 & 10 & C. albicans & No & Nonoperative & 74 & 74 & Died \\
6 & 12 & S. aureus & Yes & Mediastinal debridement & 3 & 8 & Survived \\
7 & 9 & Methicillin-resistant S. aureus & Yes & Nonoperative & 11 & 27 & Died \\
8 & 26 & Coagulase-negative S. aureus & Yes & Mediastinal debridement & 32 & 76 & Survived \\
\hline
\end{tabular}

$I C U$, Intensive care unit.

Two patients had infection of aortic graft prosthesis without sternal wound involvement. One patient had Marfan syndrome and had originally undergone a composite aortic root replacement with a mechanical valve conduit. He presented 28 days after surgery with a Candida albicans PGI. This was complicated by false aneurysm of the ascending aorta. This patient underwent a successful redo aortic root replacement with a composite porcine xenograft.

The second patient underwent a composite aortic root replacement plus partial replacement of the aortic arch. She presented weeks after surgery with $C$. albicans PGI. It was elected to treat her conservatively with antifungal agents. She died of multiorgan failure secondary to mediastinal sepsis 10 weeks after the initial operation.

The median intensive therapy unit stay was 8 days (range 3-74 days). The median survival for the 6 patients discharged from the hospital was 5.8 years (range $0.25-7$ years). There was 1 late death 6 years after the procedure. No patient had recurrence of sepsis affecting either the wound or the aortic prosthesis (Table 2).

\section{Discussion}

PGI after aortic reconstruction represents a difficult problem to mange. Redo surgery is technically challenging and mortality rates remain high, up to $42 \%$ even with an aggressive surgical strategy. ${ }^{1,2}$

In this report we showed that the incidence of PGI after surgery of the thoracic aorta is low (2\%) and mostly related to sternal wound sepsis. When associated with sternal wound sepsis, a limited surgical strategy involving extensive mediastinal debridement and mediastinal irrigation resulted in a good outcome in the majority of cases. Removal of the infective prosthesis was not required. Cases in which the graft was infected without sternal wound involvement were unusual. In these cases, removal of the infected prosthesis and reconstruction of the aorta are recommended. In all cases, the best outcome was achieved with prompt surgery.

\section{References}

1. Darouiche R. Treatment of infections associated with surgical implants N Engl J Med. 2004;350:1422-9.

2. Coselli JS, Koksoy C, LeMaire SA. Management of thoracic aortic graft infections. Ann Thorac Surg. 1999;67:1990-3.

3. Soyer R, Bessou JP, Bouchart F, Redonnet M, Arrignon J. Surgical treatment of infected composite graft after replacement of ascending aorta. Ann Thorac Surg. 1994;58:425-8.

4. Coselli JS, Crawford ES, Williams TW Jr, Bradshaw MW, Wiemer DR, Harris RL, et al. Treatment of postoperative infection of ascending aorta and transverse aortic arch, including use of viable omentum and muscle flaps. Ann Thorac Surg. 1990;50:868-81.

5. Mitra A, Spears J, Perrotta V, McClurkin J, Mitra A. Salvage of infected prosthetic grafts of the great vessels via muscle flap reconstruction. Chest. 2005;128:1040-3. 